\title{
STAT3 mutations are frequent in T-cell large granular lymphocytic leukemia with pure red cell aplasia
}

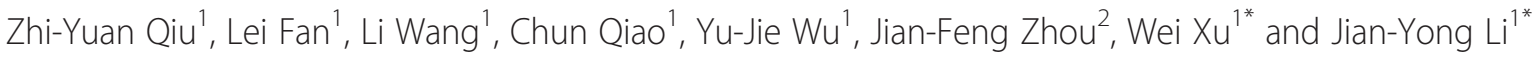

\begin{abstract}
T-cell large granular lymphocytic leukemia (T-LGLL) is a rare lymphoproliferative disorder and can cooccur in the context of pure red cell aplasia (PRCA). The aim of the current study was to analyze the signal transducer and activator of transcription 3 (STAT3) mutation status and its clinical significance in T-LGLL. We found STAT3 mutations in $21.4 \%$ of patients with T-LGLL. High $\beta 2-M G$ ( $\beta 2$-microglobulin) levels $(P=0.005)$, neutropenia $(P=0.018)$ and PRCA $(P=0.001)$ all displayed a significant association with STAT3 mutations. In univariate analysis, treatment-free survival (TFS) was affected by STAT3 mutation status $(P=0.008)$ and $\beta 2-\mathrm{MG}(P=0.006)$. Our results demonstrate the remarkable correlation of STAT3 mutation with PRCA, neutropenia and $\beta 2-M G$.
\end{abstract}

Keywords: STAT3, T-LGLL, PRCA, $\beta 2-M G$

\section{To the editor}

T-cell large granular lymphocytic leukemia (T-LGLL) is a rare lymphoproliferative disorder and can cooccur in the context of pure red cell aplasia (PRCA) [1-3]. Recently, recurrent somatic mutations in the Src homology domain of the signal transducer and activator of transcription 3 (STAT3) gene have been identified to have a high frequency of 40\% [4] and 33\% [5] in TLGLL. To analyze the STAT3 mutation status and its clinical significance, we investigated STAT3 mutations in 28 consecutive patients with newly diagnosed TLGLL who were recruited between January 2007 and January 2013. The diagnosis of T-LGLL was based on the WHO criteria [1]. The diagnosis of PRCA was defined according to the previous report [6].

\section{Findings}

For STAT3 mutation screening, genes of exons 20 and 21 of STAT3 were amplified by PCR and sequenced.
Five different mutations (Y640F, D661Y, E616V, V671F, S614R) were observed, and two mutations, E616V and $\mathrm{V} 671 \mathrm{~F}$, had not been previously reported. STAT3 is an oncogene, and its activation plays a key role in cell signaling in many types of cancer [7]. In our study, all mutations were heterozygous and the mutational hot spot were located close to the transcriptional activation domain.

Seven patients $(25 \%)$ were found to have both T-LGLL and PRCA. STAT3 mutation was more common among patients with PRCA than those without PRCA (71.4\% vs.4.8\%, $P=0.001)$. Six of $7(85.7 \%)$ patients with PRCA were found to have elevated $\beta 2$-MG ( $\beta 2$-microglobulin), which was significantly higher than was found in 6 of 18 (33.3\%) patients without PRCA $(P=0.030$, Table 1$)$. On the other hand, patients with STAT3 mutations had presented with neutropenia more often than those without STAT3 mutations $(100 \%$ vs. $40.9 \%, P=0.018)$, and this is similar to previous studies [4].

\footnotetext{
* Correspondence: xuwei10000@hotmail.com; lijianyonglm@medmail.com.cn ${ }^{1}$ Department of Hematology, the First Affiliated Hospital of Nanjing Medical University, Jiangsu Province Hospital, Nanjing 210029, China

Full list of author information is available at the end of the article
} 
Table 1 Comparison of clinical characteristics between T-LGLL patients with or without PRCA

\begin{tabular}{|c|c|c|c|}
\hline & Patients with PRCA (7) & Patients without PRCA (21) & $P$ \\
\hline Gender & & & 1.000 \\
\hline Male & $3(42.9)$ & $8(38.1)$ & \\
\hline Female & $4(57.1)$ & $13(61.9)$ & \\
\hline Age & & & 0.668 \\
\hline Mean \pm SD & $57.3 \pm 10.2$ & $55.4 \pm 9.0$ & \\
\hline $\mathrm{LDH}$ & & & 0.165 \\
\hline$>250 \mathrm{U} / \mathrm{L}$ & $4(57.1)$ & $5(23.8)$ & \\
\hline$<250 \mathrm{U} / \mathrm{L}$ & $3(42.9)$ & $16(76.2)$ & \\
\hline$\beta 2-M G(n=25)$ & & & 0.030 \\
\hline$>3.0 \mathrm{mg} / \mathrm{L}$ & $6(85.7)$ & $6(33.3)$ & \\
\hline$<3.0 \mathrm{mg} / \mathrm{L}$ & $1(14.3)$ & $12(66.7)$ & \\
\hline Neutropenia, no.\% & $6(85.7)$ & $9(42.9)$ & 0.084 \\
\hline Lymphocytosis, no.\% & $4(57.1)$ & $11(52.4)$ & 1.000 \\
\hline LGL count in $\mathrm{PB}, \times 10^{9} / \mathrm{L}$ & & & 0.295 \\
\hline Mean \pm SD & $3.2 \pm 2.1$ & $2.9 \pm 1.7$ & \\
\hline Splenomegaly, no. (\%) & $5(71.4)$ & $5(23.8)$ & 0.063 \\
\hline STAT3 mutation & $5(71.4)$ & $1(4.8)$ & 0.001 \\
\hline
\end{tabular}

PB: peripheral blood; STAT3: signal transducer and activator of transcription 3; Anemia:hemoglobin $(\mathrm{Hb})<100 \mathrm{~g} / \mathrm{L}$; Neutropenia: absolute neutrophil count (ANC) $<1.5 \times 10^{9} / \mathrm{L}$.

LDH: lactic dehydrogenase.

Anemia, neutropenia and rheumatoid arthritis (RA) are common complications, and anemia is more common in Asian countries [8,9]; neutropenia and RA is more common in Western countries [10,11], but there was no patients with RA in our study. We show here that the coexistence of PRCA or neutropenia is more frequent in patients with STAT3 mutation. This observation varies from from the study of Jerez et al. [5] and Koskela et al. [4], but is consistent with the study from Japan [12].

TFS was defined as the period from the diagnosis date to the time of the first treatment. In our study, we observed a significant difference between patients with or without STAT3 mutations in TFS (median 6.5 months vs. 16.6 months, $P=0.008$, Figure $1 \mathrm{~A}$ ), and we observed a significant difference between the high $\beta 2-M G$ group and the low $\beta 2-M G$ group in TFS $(P=0.003$ Figure $1 C)$. TFS was not related to LDH levels (Figure 1B).

To our knowledge, our study is the first report on STAT3 mutation status in patients with T-LGLL in China. Although the STAT3 mutation thus likely contributes to the pathogenesis of T-LGLL, patients without STAT3 mutations are characterized by significant

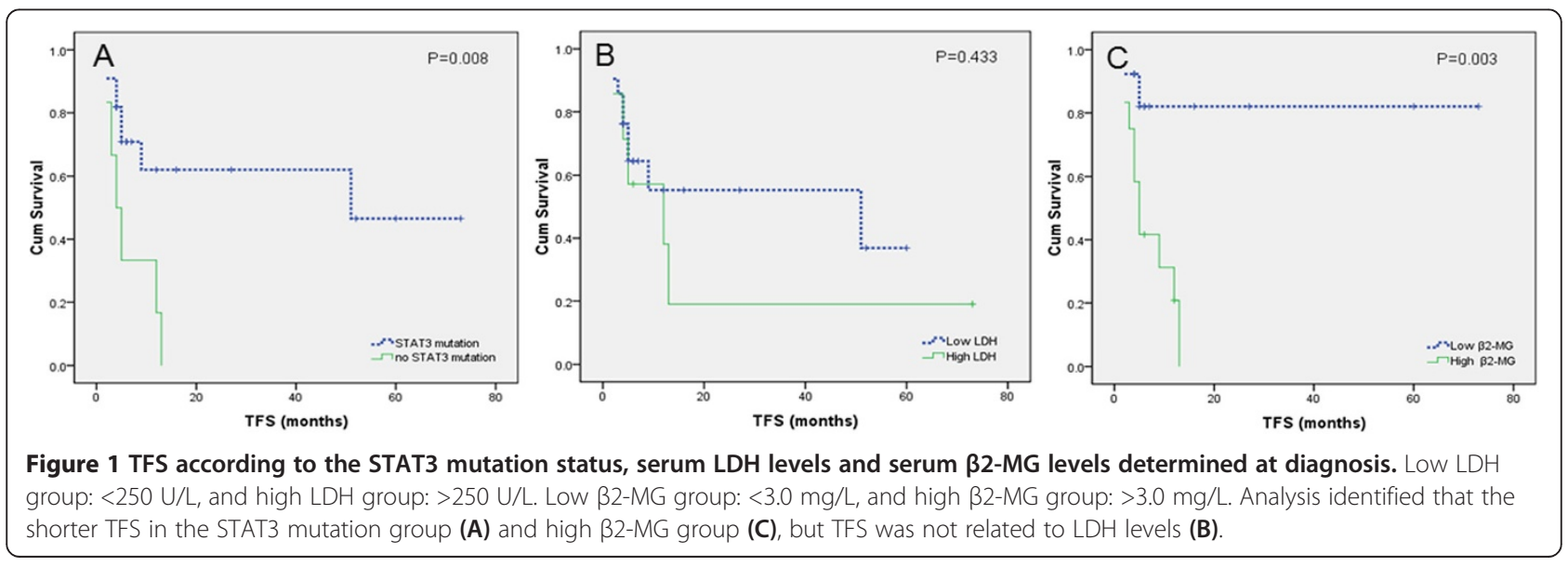


heterogeneity, indicating that other mechanisms of STAT3 activation can be operative in this disease. Further studies are therefore necessary to determine other reasons to lead to the pathogenesis of T-LGLL.

\section{Abbreviations}

T-LGLL: T-cell large granular lymphocytic leukemia; STAT3: Signal transducer and activator of transcription 3; PRCA: Pure red blood cell aplasia; LDH: Lactic dehydrogenase; $\beta 2-M G$ : $\beta 2$-microglobulin; TFS: Treatment-free survival; PB: Peripheral blood; ANC: Absolute neutrophil count; RA: Rheumatoid arthritis.

\section{Competing interests}

The authors declare that they have no competing interests.

\section{Authors' contributions}

ZYQ performed the laboratory work for this study and wrote the manuscript; LF and LW provided material and clinical information; CQ and YJW designed the experiments; JFZ analyzed data; WX and JYL performed statistical analysis and wrote the manuscript. All authors have approved the final version of the manuscript.

\section{Acknowledgements}

This study was supported by the National Natural Science Foundation of China (Grant Nos. 30871104, 30971296, 81170485, 81170488), the Natural Science Foundation of Jiangsu Province (Grant No. BK2010584), Key Projects of Health Department of Jiangsu Province (Grant No. K201108), Jiangsu Province's Medical Elite Program (Grant No. RC2011169), National Public Health Grand Research Foundation (No.201202017), Project Funded by the Priority Academic Program Development of Jiangsu Higher Education Institute (No. JX10231801), the Program for Development of Innovative Research Teams in the First Affiliated Hospital of Nanjing Medical University, and Project of National Key Clinical Specialty.

\section{Author details}

${ }^{1}$ Department of Hematology, the First Affiliated Hospital of Nanjing Medical University, Jiangsu Province Hospital, Nanjing 210029, China. ${ }^{2}$ Department of Hematology, Tongji Medical College, Huazhong University of Science and Technology, Tongji Hospital, Wuhan, China.

Received: 24 October 2013 Accepted: 27 October 2013

Published: 31 October 2013

\section{Reference}

1. Swerdlow SH, International Agency for Research on Cancer, World Health Organization: WHO Classification of Tumours of Haematopoietic and Lymphoid Tissues(4th Ed). Lyon, France: International Agency for Research on Cancer; 2008.

2. Abkowitz JL, Kadin ME, Powell JS, Adamson JW: Pure red cell aplasia: lymphocyte inhibition of erythropoiesis. Br J Hematol 1986, 63:59-67.

3. Lamy T, Loughran TP Jr: How I treat LGL leukemia. Blood 2011, 117:2764-2774.

4. Koskela HL, Eldfors S, Ellonen P, van Adrichem AJ, Kuusanmäki H, Andersson El, et al: Somatic STAT3 mutations in large granular lymphocytic leukemia. N Engl J Med 2012, 366(20):1905-1913.

5. Jerez A, Clemente MJ, Makishima H, Koskela H, Leblanc F, Peng Ng K, et al: STAT3 mutations unify the pathogenesis of chronic lymphoproliferative disorders of NK cells and T-cell large granular lymphocyte leukemia. Blood 2012, 120(15):3048-3057.

6. Kwong YL, Wong KF, Liang RH, Chu YC, Chan LC, Chan TK: Pure red cell aplasia: clinical features and treatment results in 16 cases. Ann Hematol 1996, 72:137-140.

7. Bromberg JF, Wrzeszczynska MH, Devgan G, Zhao Y, Pestell RG, Albanese C, et al: Stat3 as an oncogene. Cell 1999, 98:295-303.

8. Kwong YL, Au WY, Leung AY, Tse EW: T-cell large granu1ar lymphocyte leukemia: an Asian perspective. Ann Hematol 2010, 89(4):331-339.

9. Kawahara S, Sasaki M, Isobe Y, Ando J, Noguchi M, Koike M, et al: Clinical analysis of 52 patients with granular lymphocyte proliferative disorder (GLPD) showed frequent anemia in indolent T-cell GLPD in Japan. Eur J Haematol 2009, 82:308-314.
10. Burks EJ, Loughran TP Jr: Pathogenesis of neutropenia in large granular lymphocyte leukemia and Felty syndrome. Blood Rev 2006, 20:245-266.

11. Sokol L, Loughran TP Jr: Large granular lymphocyte leukemia. Oncologist 2006, 11(3):263-273.

12. Sekiguchi N, Matsuda K, Momose K, Makishima H, Ito T, Ishida F: STAT3 gene mutations and the association with pure red cell aplasia in large granular lymphocyte leukemia [abstract 2668]. 2012. 54TH ASH ${ }^{\circledR}$ Annual Meeting and Exposition.

doi:10.1186/1756-8722-6-82

Cite this article as: Qiu et al:: STAT3 mutations are frequent in T-cell large granular lymphocytic leukemia with pure red cell aplasia. Journal of Hematology \& Oncology 2013 6:82.

\section{Submit your next manuscript to BioMed Central and take full advantage of:}

- Convenient online submission

- Thorough peer review

- No space constraints or color figure charges

- Immediate publication on acceptance

- Inclusion in PubMed, CAS, Scopus and Google Scholar

- Research which is freely available for redistribution 